\section{Kidney \\ Blood Pressure Research}

Kidney Blood Press Res 2015;40:520-532

DOI: $10.1159 / 000368528$

Published online: October 20, 2015

Accepted: September 08, 2015

\title{
Molecular Mechanisms and Novel Therapeutic Approaches to Rhabdo- myolysis-Induced Acute Kidney Injury
}

\author{
Nayara Panizo Alfonso Rubio-Navarro $^{b} \quad J u a n$ Manuel Amaro-Villalobos ${ }^{b}$ \\ Jesús Egido ${ }^{b}$ Juan Antonio Morenob \\ ${ }^{a}$ Nefrovall, B-BRAUN Avitum. La Vall d' Uixó, Castellón; 'Renal, Vascular and Diabetes Research \\ Laboratory, IIS-Fundación Jiménez Díaz, Autónoma University, Madrid, Spain
}

\section{Key Words}

Myoglobin • Rhabdomyolysis • Chronic kidney disease • Acute kidney injury

\begin{abstract}
Rhabdomyolysis is a syndrome caused by injury to skeletal muscle that usually leads to acute kidney injury (AKI). Rhabdomyolysis has been linked to different conditions, including severe trauma and intense physical exercise. Myoglobin-induced renal toxicity plays a key role in rhabdomyolysis-associated kidney damage by increasing oxidative stress, inflammation, endothelial dysfunction, vasoconstriction, and apoptosis. New drugs that target the harmful effects of myoglobin have been recently developed, and some have been proven to be successful in animal models of acute renal failure secondary to rhabdomyolysis. This review aims to provide a comprehensive and updated overview of the pathological mechanisms of renal damage and describes new therapeutic approaches to this condition based on novel compounds that target key pathways involved in myoglobin-mediated kidney damage.
\end{abstract}

(C) 2015 The Author(s)

Published by S. Karger AG, Basel

\section{Introduction}

Rhabdomyolysis is the breakdown of damaged skeletal muscle and subsequent release of its contents (i.e., myoglobin, sarcoplasmic proteins, and electrolytes) into the plasma [1]. These products may be filtered through the glomeruli, leading to acute kidney injury (AKI) via different mechanisms, such as intratubular obstruction secondary to protein precipitation, renal vasoconstriction, inflammation, and tubular damage associated with reactive oxygen species (ROS) production. These harmful effects are produced in response to renal accumulation of myoglobin and heme derivates. This review aims to provide a comprehensive 


\section{Kidney Blood Pressure Research}

Kidney Blood Press Res 2015;40:520-532

\begin{tabular}{l|l}
\hline DOI: 10.1159/000368528 & (C) 2015 The Author(s). Published by S. Karger AG, Base
\end{tabular}

Published online: October 20, 2015

www.karger.com/kb

Panizo/Rubio-Navarro/Amaro-Villalobos/Egido/Moreno: Novel Therapeutic Approaches in Rhabdomyolysis

and updated overview of the complex mechanisms involved in rhabdomyolysis-associated renal damage, describing novel therapeutic approaches to this pathological condition.

\section{Epidemiology}

The global prevalence of rhabdomyolysis is not fully known and appears to be underestimated. No large epidemiologic studies or updated registers on rhabdomyolysis are available. However, American reports suggest a global prevalence of 26,000 cases per year $[2,3]$. The incidence of AKI among patients suffering from rhabdomyolysis is not exactly known, owing to different definitions of kidney injury and the etiological and population heterogeneity reported in these studies. Recent publications indicate that rhabdomyolysis causes between $7 \%$ and $10 \%$ of AKI cases each year in the United States [4]. Thus, it is estimated that AKI appears in $4 \%$ to $33 \%$ of patients with rhabdomyolysis [2].

\section{Prognosis}

Global rhabdomyolysis mortality is estimated between 2 and $46 \%$, depending of the type of cause, early treatment administration and the presence of comorbid conditions and complications [5]. Most patients recover renal function in a few months [6], however even apparently resolved, AKI due to rhabdomyolysis promotes structural alterations, such as fibrosis and glomerulosclerosis, thus resulting in increased risk of chronic kidney disease, as previously observed in other AKI circumstances [7, 8]. These long-term adverse effects may be related not only to increased extracellular matrix production by renal cells, but also to a profibrotic role of infiltrating macrophages. Thus, macrophage depletion reduced fibrosis and improved rat survival in experimental rhabdomyolysis [8]. Nevertheless, studies analyzing long-term renal function outcome for rhabdomyolysis in humans are lacking.

\section{Molecular mechanisms in rhabdomyolysis}

Massive muscular destruction can be due to various causes. It can result from direct muscle trauma (endogenous or exogenous) or muscle injury secondary to excessive muscle exertion, intrinsic metabolic alterations of muscle cells, or the toxic effects of chemical, physical, or biological agents (Figure 1) $[1,5]$. Regardless of its cause, rhabdomyolysis produces multiple adverse effects on the kidney, such as oxidative stress, inflammation, apoptosis, vasoconstriction, and tubular obstruction (Figure 2).

\section{Oxidative stress}

During rhabdomyolysis, massive amounts of myoglobin are released from muscle cells and filtered by the glomerular filtration barrier [9]. Once filtered, myoglobin is endocytosed by tubular cells through the megalin-cubilin receptors [10]. Inside tubular cells, ferrous $\left(\mathrm{Fe}^{2+}\right)$ myoglobin is oxidized to a ferric $\left(\mathrm{Fe}^{3+}\right)$ form, leading to the formation of a hydroxyl radical, the most reactive of the ROS. In order to be stable, ferric myoglobin is transformed to ferryl $\left(\mathrm{Fe}^{4+}\right.$ ) myoglobin by redox cycling, yielding radical species. These radical species promote lipid peroxidation of membrane fatty acids $[11,12]$ and induce malondialdehyde synthesis, which mediates alterations of proteins and DNA $[13,14]$. Lipid peroxidation of fatty acids results in the production of F2-isoprostanes, as observed in the urine of affected patients [15]. F2-isoprostanes are potent vasoconstrictors and promote the expression of intercellular adhesion factors such as VCAM-1 (vascular cell adhesion molecule-1) or intercellular adhesion molecule-1 (ICAM-1) as well as pro-inflammatory cytokines (MCP1 ), which promotes macrophage recruitment $[8,16,17]$.In addition, the highly reactive 


\section{Kidney

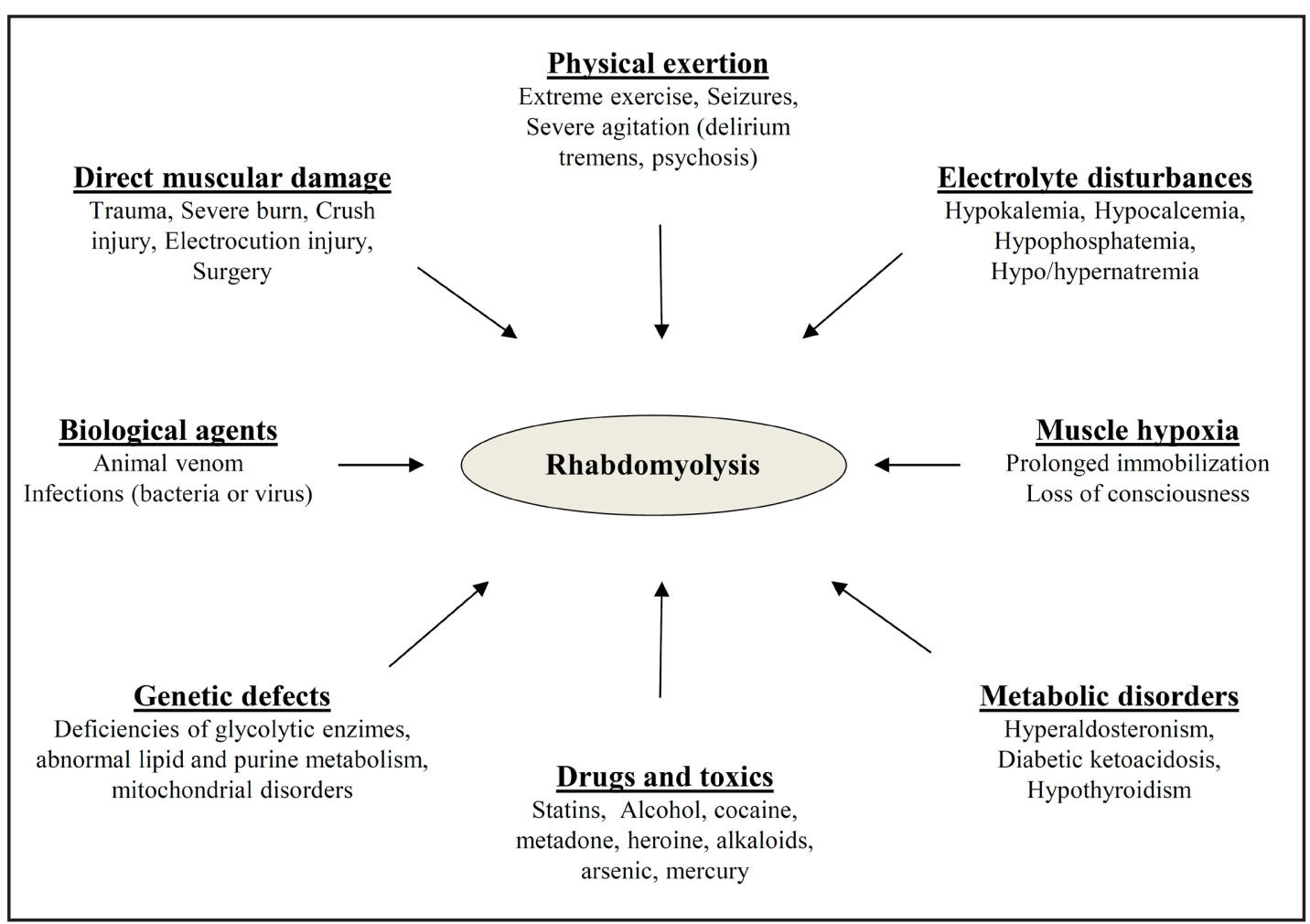

Fig. 1. Principal causes of rhabdomyolysis.



Fig. 2. Molecular mechanisms in rhabdomyolysis. NF-k $\beta$, Nuclear factor kappa B; RAAS, renin angiotensin aldosterone system; TGF- $\beta$, transforming growth factor-beta. 


\section{Kidney Blood Pressure Research}

Kidney Blood Press Res 2015;40:520-532

DOI: 10.1159/000368528

Published online: October 20, 2015

(c) 2015 The Author(s). Published by S. Karger AG, Base

www.karger.com/kbr

Rhabdomyolysis

ferrylmyoglobin, which is found in the urine of patients with rhabdomyolysis [18], acts as a potent nitric oxide scavenger, contributing to vasoconstriction, endothelial dysfunction, and platelet aggregation [11]. It is important to note that oxidation of myoglobin is a pHdependent process. Alkaline media tend to stabilize the ferryl species, making myoglobin less reactive [4].

\section{Inflammation}

Rhabdomyolysis-damaged muscle cells release immunostimulatory molecules, such as ligand high mobility group box proteins-1 (HMGB1), DNA, microRNAs and uric acid. These molecules reach kidney tissue, where they activate recently infiltrated dendritic cells, T-lymphocytes, and macrophages through the activation of complement cascade, Toll-like receptors (TLRs), and nuclear factor kappa beta (NF- $\kappa \beta$ ). Activation of these inflammatory cells promotes the production of pro-inflammatory cytokines, such as transforming growth factor beta (TGF- $\beta$ ) and tumor necrosis factor alpha (TNF- $\alpha$ ), thus resulting in the maintenance of a pro-inflammatory status [17, 19-21].

Myoglobin-derived heme also promotes pro-inflammatory effects on endothelial and tubular epithelial cells. Thus, cultured endothelial cells exposed to heme show an enhanced expression of the adhesion molecules ICAM-1 and VCAM-1 as well as E-selectin, thus leading to endothelial dysfunction [22]. Additionally, heme up-regulates $\alpha$-chemokine and interleukin-8 (IL-8) gene expression and activates neutrophil protein kinase C [23]. In response to heme, endothelial and tubular renal cells also release pro-inflammatory mediators, resulting in a positive feedback that perpetuates inflammatory response. As a result, infiltrated macrophages produce multiple cytokines such as TNF- $\alpha$, IL-1 $\beta$, and interferon- $\gamma$. Indeed, the number of infiltrated macrophage and pro-inflammatory cytokine levels has been positively correlated with loss of renal function and histologic injury in vivo [24]. It is well known that sterile inflammation triggered by tissue injury can be mediated through multiprotein complexes called the inflammasomes. In a recent article, it was reported that NLRP3 inflammasomes contributes to inflammation and tissue injury during the early phase of rhabdomyolysis-AKI [25]. In this pro-inflammatory scenario, renal cells may undergo dedifferentiation, acquiring the ability to proliferate, migrate, and produce extracellular matrix and pro-fibrotic mediators involved in glomerulosclerosis [7].

\section{Apoptosis}

One of the main regulators of ROS production and cell death is the mitochondria. In rhabdomyolysis, lipid peroxidation induces distortion of mitochondrial membrane permeability, resulting in a drop in cellular respiratory control, with amplification of ROS production, cytochrome $\mathrm{C}$ release, activation of caspases 1 and 3 , and tubular-cell apoptosis $[26,27]$. NLPR3 inflammasomes might also have a role in apoptosis because of its capability to activate caspase- 1 pathway [25]. Inhibition of caspase 1 and 3 resulted in amelioration of renal damage in an experimental animal model of rhabdomyolysis [28]. The activation of c-JunN-terminal kinase (JNK) p38, the extracellular signal regulated kinase (ERK) pathways are involved in apoptosis control [29]. Either ERK or JNK is activated in rodent models of myoglobinuric AKI [30].

\section{Vasoconstriction}

A number of studies show that renal vasoconstriction associated with rhabdomyolysis is related to activation of the renin angiotensine aldosterone system (RAAS), which is induced by volume depletion secondary to fluid sequestration within damaged muscle. Another factor contributing to vasconstriction is the imbalance between vasocontrictors and vasodilator products that regulate renal blood flow. These factors are altered because of endothelial dysfunction [31],decreased oxide nitric bioavailability, and increased myoglobin-mediated F2-isoprostane production, having a potent vasoconstrictor effect $[4,11]$. 


\section{Kidney Blood Pressure Research}

Kidney Blood Press Res 2015;40:520-532

\begin{tabular}{l|l}
\hline DOI: 10.1159/000368528 & (C) 2015 The Author(s). Published by S. Karger AG, Basel
\end{tabular}

Published online: October 20, 2015

www.karger.com/kb

\section{Intratubular obstruction}

In the tubular lumen, myoglobin may precipitate in combination with the Tamm-Horsfall protein, forming tubular casts, especially in presence of acid $\mathrm{pH}$. This process is promoted by volume depletion, resulting in concentrated urine [1]. However, some authors indicate that tubular obstruction is merely the result of tubular-cell precipitation with myoglobin, and consequently does not need specific interventions other than preventing cellular death [11].

\section{Molecular mechanisms involved in protection against rhabdomyolysis-induced renal damage}

The main protective mechanism against myoglobin toxicity is mediated by hemeoxygenase (HO), an antioxidant enzyme involved in heme degradation. HO-1 is the inducible isoform of HO, which is activated in the presence of several agents, including IL-6, IL-10, TNF- $\alpha$, and ROS [32]. HO-1 knockout mice are more sensitive to rhabdomyolysis-associated AKI, showing increased creatinine and lactate dehydrogenase (LDH) plasma levels as well as elevated mortality [33]. The enzymatic degradation of heme by HO-1 produces carbon monoxide (CO), free iron, and biliverdin. $\mathrm{CO}$ is a potent ROS scavenger and inhibits the expression of pro-inflammatory cytokines such as TNF- $\alpha$ and IL- $1 \beta$ while promoting the expression of the anti-inflammatory cytokine IL-10 [34]. When released from heme, iron is incorporated into ferritin, decreasing free iron levels and protecting cells from oxidative stress. Ferritin also has anti-apoptotic effects. HO-1 promotes ferritin synthesis [35]. Finally, biliverdin is transformed into bilirubin by biliverdinreductase. Biliverdin promotes an antiinflammatory response in macrophages [36]. Moreover, biliverdin and bilirubin are potent ROS scavengers [17].

\section{Renal damage biomarkers in rhabdomyolysis}

\section{Classic biomarkers}

Plasma detection of muscle-derived components has been used effectively for diagnosis of rhabdomyolysis. Hyperphosphatemia induces both phosphate and calcium deposition in the muscle, leading to initial hypocalcemia [36]. Calcium is later released during muscle necrosis. Additionally, increased hyperuricemia, carbonic anhydrase III and other proteases, such as LDH and aspartate aminotrasferase (AST), are observed. Increased urinary excretion of creatinine, uric acid, and glucose is also present due to the associated tubular damage [37].

\section{New biomarkers}

New early predictors of AKI in both blood and urine have been described in rhabdomyolysis. These biomarkers allow an earlier diagnosis as they provide indication of the development of incipient mechanisms before loss of renal function. Elevation of these biomarkers may be useful for early treatment administration and effective patient followup. NGAL (neutrophil gelatinase-associated lipocalin) is the most widely investigated biomarker in rhabdomyolysis [38]. In the presence of toxic or ischemic injury, its production and liberation increase quickly, becoming detectable in urine and blood as a sensitive and specific renal-injury biomarker [39]. Moreover, NGAL levels have been positively correlated with mortality [40].

KIM-1 is an early biomarker of tubular damage. KIM-1 expression is increased in humans suffering from AKI secondary to renal ischemia due to cardiac surgery. An association between KIM-1 elevation and both the extrarrenal depuration treatment requirements and mortality has been reported. However, these biomarkers have no application in clinical practice to date [41] 


\section{Kidney Blood Pressure Research}

Kidney Blood Press Res 2015;40:520-532

DOI: 10.1159/000368528

Published online: October 20, 2015

(c) 2015 The Author(s). Published by S. Karger AG, Base

www.karger.com/kbr

\section{Global therapeutic approach}

\section{Classic strategies}

Intensive fluid resuscitation has been effectively used in rhabdomyolysis treatment. It is important to monitor diuresis rate and stop fluid infusion if signals of overhydration appear [5, 42]. Alkalinization with intravenous bicarbonate has also shown benefits in animal models by reducing cast formation by inhibiting precipitation of myoglobin with Tamm-Horsfall protein. Moreover, myoglobin oxidation is inhibited by alkalinization [15, 43]. However, human studies validating the employment of bicarbonate in patients suffering from rhabdomyolysis are scarce. These studies are either hindered by a small simple size or employ different combinations of alkaline agents, making it impossible to fully establish the efficacy of alkalization. In addition, alkalization is not always harmless, since it can worsen hypocalcemia in the early stages of rhabdomyolysis, stimulating the precipitation of calcium and phosphorus in muscle tissue [44, 45].

Once euvolemia is restored, the use of diuretics is sometimes necessary, although their use is controversial. Mannitol is an osmotic diuretic that increases urinary flow, prevents myoglobin precipitation, and has ROS scavenging capacity $[2,46]$. In mice with rhabdomyolysis, it has been observed that mannitol administration along with bicarbonate reduces oxidative stress and restores urinary flow to a greater extent than fluid resuscitation alone [47]. However, no randomized clinical trials are available in humans, although some retrospective reports showed no beneficial effect on either renal function or mortality [44]. Similarly, the use of the loop diuretics furosemide and torasemide has not been specifically recommended in rhabdomyolysis, being used as in other AKI circumstances [48].

In cases of rhabdomyolysis, fluid and electrolyte disturbances should always be detected in early stages and carefully treated. The presence of refractory hypercalcemia, metabolic acidosis, or refractory oligoanuria calls for the use of renal replacement therapy either by conventional hemodialysis or continuous renal replacement therapy (CRRT). Conventional hemodialysis does not eliminate myoglobin because of its high molecular weight. Therefore, although hemodialysis resolves the effects of renal dysfunction such as uremia and fluid overload, it does not prevent the toxic effects of myoblobinon kidneys. Nevertheless, some authors have reported effective removal of myoglobin when high-flux dialyzers are employed for hemodialysis in patients with myoglobinuric AKI $[49,50]$. Similarly, high cutoff membranes with larger pore sizes have been shown to be effective in removing myoglobin [51]. A randomized open clinical trial comparing the new high cut-off dyalizerSepte $X ®$ vs. conventional high-flux dialysis treatment to eliminate plasma myoglobin is currently under way (NCT01467180). CRRT is also capable of eliminating myoglobin, especially when high convective volumes are employed [52]. A study in dogs has revealed that CRRT-mediated myoglobin reduction protects kidney tissue by reducing mitochondrial dysfunction, and consequently cellular apoptosis [53]. Plasma exchanges with plasmapheresis have also produced good results in cases of rhabdomyolysis $[54,55]$.

\section{New therapeutic strategies}

Iron chelators and antioxidant treatment. Desferrioxamine is an iron chelator that decreases rhabdomyolysis-derived kidney injury in rats [56] and inhibits lipid peroxidation by reducing myoglobin to its ferrous form [57]. However, desferroxamine has direct nephrotoxic effects, which are enhanced by its hydrophilic nature. This limitation can be resolved by conjugating desferrioxamine to adamantyl derivatives, obtaining desferrioxamine B-N-(3hydroxyadamant-1-yl), which is lipophilic and less cytotoxic than original desferrioxamine and preserves the anti-inflammatory and antioxidant capacity, as demonstrated in animal models [58]. The oral alternatives to desferrioxamine are $\alpha$-hidroxipyridines, such as deferiprone, which has been effectively tested in large clinical trials and is currently available for clinical use in situations of ferrous overload by repeated blood transfusions [59]. However, there are no studies testing its efficacy to prevent or treat AKI in rhabdomyolysis. 


\section{Kidney Blood Pressure Research}

Kidney Blood Press Res 2015;40:520-532

DOI: 10.1159/000368528

Published online: October 20, 2015

(c) 2015 The Author(s). Published by S. Karger AG, Base

www.karger.com/kbr

Antioxidant treatment. Acetaminophen is a peroxidase substrate that inhibits lipid peroxidation by reducing ferryl myoglobin to the ferric state [60]. In animal models of rhabdomyolysis, treatment with this agent reduced urinary levels of F2-isoprostanes and ferrylmyoglobin, with consequent reduction in lipid peroxidation, kidney damage, and loss of proximal tubular cells [61].The effects of acetaminophen did not depend on muscle damage reduction because myoglobin deposits in treated kidneys were present to the same extent as in untreated kidneys. Interestingly, this effect was observed when acetaminophen was given both before and after inducing the injury, indicating that this drug can be used not only for prophylaxis but also for treatment [11].

$\mathrm{N}$-acetylcysteine (NAC) is a source of glutathione and sulfhydryl (GSH) groups in cells and has ROS scavenger capacity [11]. The protective effects of NAC have been proven in models of cisplatin-induced nephrotoxicity [62], ischemia-reperfusion injury [63], and chronic kidney disease [64]. NAC also reduced renal damage in a rat model of rhabdomyolysis, preventing celular apoptosis via inhibition of ERK and JNK signaling pathways and oxidative stress [65]. A randomized double-blinded trial comparing the efficacy of CRRT and N-acetylcysteine in preventing renal failure in rhabdomyolysis has recently been completed, although the results have not yet been published (NCT00391911).

Vitamin E ( $\alpha$-tocopherol) is the major lipophilic antioxidant present in cellular membranes, protecting them against lipid peroxidation [66]. For this reason, it has been suggested as a possible protective molecule to prevent myoglobin tubular toxicity [67]. However, its liposolubility implies a low capacity to prevent the initial myoglobin oxidation in the urine [11]. Vitamin C (ascorbic acid) also has antioxidant effects but has the advantage of being water soluble, and is probably capable of blocking the oxidation of myoglobin in the urine [11]. Polyphenols are lipid-soluble antioxidants that have synergic effects with vitamin C. In a murine model of rhabdomyolysis, rats were treated either with 3,3',5,5'-tetratert-butyl-biphenyl-4,4'-diol or with vitamin C [68]. The authors of the study observed that both compounds protected the kidney from oxidative damage and inflammation by inhibiting ERK-mediated MCP-1 production. Nevertheless, only animals treated with vitamin $\mathrm{C}$ presented some clinical benefit (reduction in proteinuria and hyperuricemia). This result suggests that vitamin $\mathrm{C}$ may have some additional effect besides its antioxidant role.

Daily administration of flavonoids from red wine reduced blood CPK as well as cathalase, glutathione peroxidase, and superoxide dismutase expression in a rat model of rhabdomyolysis [69].

The potential utility of L-carnitine in myoglobinuric AKI has also been demonstrated [70]. Thus, administration of L-carnitine significantly decreased CPK, creatinine, and urea levels as well as necrosis, iron accumulation, and cast formation as compared to the control group.

Anti-inflammatory treatments. Liposome-encapsulated clodronate (LEC) administration is a well-known method for depleting mononuclear phagocytes in mice. Phagocytes incorporate LEC and undergo apoptosis [71]. Treatment with LEC in a mouse model of rhabdomyolysis led to depletion of infiltrating macrophages, causing preservation of renal function and decreased NF- $\kappa \beta$ mediated inflammatory response and production of profibrotic mediators such as TGF- $\beta$ [24, 72]. Moreover, LEC treatment reduced the expression of extracellular matrix molecules such as MMP-2 and MMP-9 in both infiltrating inflammatory and tubular cells. This effect was not attributable to muscular protection because no differences in CPK were observed between groups [24].

Suramine is a polysulfonated naphtylurea used in humans to treat trypanosomiasis. It has been demonstrated that this compound accelerates recovery from AKI due to ischemia/ reperfusion injury, obstructive nephropathies, and renal fibrosis in mice [73]. In one study, suramine was employed in rats with rhabdomyolysis, resulting in amelioration of kidney function and histology [74]. In fact, treated animals showed decreased KIM-1 renal expression, inhibition of apoptosis by reduction of caspase- 3 activation, and decreased 


\section{Kidney Blood Pressure Research}

Kidney Blood Press Res 2015;40:520-532

DOI: 10.1159/000368528

Published online: October 20, 2015

(c) 2015 The Author(s). Published by S. Karger AG, Base

www.karger.com/kbr

Panizo/Rubio-Navarro/Amaro-Villalobos/Egido/Moreno: Novel Therapeutic Approaches in Rhabdomyolysis

inflammation, as denoted by reduced NF- $\kappa \beta$ activation and consequent reduction in IL-1 $\beta$, ICAM-1, and leukocyte infiltration.

Pentoxifylline is a substituted methylxanthine with protective properties caused by adenosine receptor antagonism. Pentoxifylline inhibits proliferation of rat mesangial cells and mRNA collagen expression [75] as well as inhibiting myofibroblasts differentiation [76]. Treatment with pentoxifylline in a rat model of myoglobinuric AKI reduced interstitial mononuclear cell infiltration [77].

Mesenchymal stem-cell (MSC) administration has shown protective effects against rhabdomyolysis-induced kidney damage in mice [78]. Despite the fact that some authors have observed that MSC migration and trans-differentiation into functional parenchymal cells can exert reparative actions, its beneficial effects are mainly ascribed to their paracrine actions. It has been suggested that MSC presence promotes intra-renal accumulation of protective M2 macrophages, with increased production of the anti-inflamatory IL-10 and decrease of IL- 6 and TNF- $\alpha$ [79]. In humans, stem-cell based therapy has been tried for stroke, with apparently good results, however different recent meta-analysis report that further investigation is needed to test clinical efficacy and safety [80, 81].

Regarding elimination techniques, an ongoing clinical trial is evaluating the efficacy of a new extracorporeal blood filter, Cytosorb®, in rhabdomyolysis (NCT02111018). This cartridge is a polymer with immunomodulatory actions by adsorbing cytokines, such as TNF-alpha, IL-1beta, IL-6 and IL-8, as blood pass through the device [82]. Some studies have shown its beneficial effects on the inflammatory response and survival rate in septic rats [83]. Moreover, in critically ill patients, treatment with cytokine adsorbing columns resulted effective on hemodynamics and organ failure [84]. Nevertheless, it is not well understood whether this filter can also eliminate protective anti-inflammatory cytokines, therefore reducing the natural anti-inflammatory response [85].

\section{Vasoconstriction inhibition}

Vasoconstriction is a partial consequence of nitric oxide scavenging by myoglobin; therefore, agents capable of increasing nitric oxide have been tested to prevent rhabdomyolysis-induced damage. L-arginine (nitric oxide precursor) and moldosine (nitric oxide donor) exhibited nefroprotective effects in animal models of rhabdomyolysisassociated AKI [86]. F2-isoprostanes exert their vasoconstrictor effect through tromboxanereceptor activation. This is why tromboxane receptor blockers could play a protective role in rhabdomyolysis, as has been demonstrated recently [87]. It has been confirmed that there are erythropoietin receptors (EPO-R) on tubular cells. Recombinant erythropoietin (rhEPO) can protect these cells from ischemia-reperfusion and cisplatin toxicity [88]. Moreover, in animal models of rhabdomyolysis, it has been observed that treatment with rhEPO leads to a reduction in renal damage and amelioration of renal function by decreasing $\mathrm{NF}-\kappa \beta$ activation [89]. As far as we know, no studies in humans have been developed to test the efficacy of rhEPO in rhabdomyolysis. However, given the increased risk of hypertension, cancer and thromboembolic events associated to this agent, result necessary to take care when trying to validate its clinical use for an indication different from the already admitted in humans [90].

\section{Conclusion}

A variety of mechanisms lead to kidney damage in rhabdomyolysis. One of the most important is kidney hypoperfusion secondary to fluid sequestration within damaged muscle and to vasoconstriction due to RAAS activation. Hypoperfusion is also a result of intratubular myoglobin presence causing overproduction of vasoconstrictive agents and vasodilators reduction. Additionally, intratubular myoglobin induces oxidative stress, inflammation, and tubular obstruction. Classical treatments including fluid infusion and alkalization restore renal function by increasing volemia and inhibiting tubular obstruction; however, their use 


\section{Kidney \\ Blood Pressure Research}

Kidney Blood Press Res 2015;40:520-532

\begin{tabular}{l|l}
\hline DOI: $10.1159 / 000368528$ & (C) 2015 The Author(s). Published by S. Karger AG, Basel
\end{tabular}

Published online: October 20, 2015 www.karger.com/kbr

Panizo/Rubio-Navarro/Amaro-Villalobos/Egido/Moreno: Novel Therapeutic Approaches in Rhabdomyolysis

Table 1.

\begin{tabular}{|c|c|c|c|c|c|c|}
\hline $\begin{array}{l}\text { Type of } \\
\text { treatment }\end{array}$ & Drug/Strategy & Protective mechanism & $\begin{array}{l}\text { Reduced } \\
\text { renal } \\
\text { damage }\end{array}$ & $\begin{array}{c}\text { Clinical } \\
\text { Trial }\end{array}$ & & $\begin{array}{l}\text { Refer- } \\
\text { ences }\end{array}$ \\
\hline $\begin{array}{l}\text { Iron } \\
\text { chelators }\end{array}$ & Desferrioxamine & $\begin{array}{l}\text { Decreased lipid peroxidation and } \\
\text { inflammation }\end{array}$ & Yes & No & $\begin{array}{l}\text { Rats, } \\
\text { Mice }\end{array}$ & {$[57,58]$} \\
\hline \multirow[t]{6}{*}{ Antioxidants } & Acetaminophen & Reduced lipid peroxidation & Yes & No & Rats & [61] \\
\hline & $\mathrm{N}$-acetylcysteine & $\begin{array}{l}\text { Increased ROS scavenging and } \\
\text { reduced apoptosis ( } \uparrow \mathrm{Bcl}-2 \text { and } \mathrm{Bcl}-\mathrm{xL} \text {, } \\
\downarrow \mathrm{Bax} \text { and Bad) }\end{array}$ & Yes & Yes & Rats & {$[64,65]$} \\
\hline & Vitamin E & Inhibited lipid peroxidation & No & No & Rats & [66] \\
\hline & Vitamin C & $\begin{array}{l}\text { Reduced oxidative stress and } \\
\text { diminished cast formation and } \\
\text { proteinuria }\end{array}$ & Yes & No & Rats & [68] \\
\hline & Flavonoids & $\begin{array}{l}\text { Reduce protein carbonilation, blood } \\
\text { CPK, and restored anti-oxidant } \\
\text { enzymes expression }\end{array}$ & Yes & No & Rats & [69] \\
\hline & L-carnitine & $\begin{array}{l}\text { Decrease necrosis, iron accumulation, } \\
\text { casts formation and oxidave stress }\end{array}$ & Yes & No & Rats & {$[70]$} \\
\hline \multirow[t]{4}{*}{$\begin{array}{l}\text { Anti- } \\
\text { inflammatory }\end{array}$} & Chlodronate & $\begin{array}{l}\text { Reduced inflammation via NF- } \kappa \beta \text { and } \\
\text { inhibited fibrosis by reducing TGF- } \beta\end{array}$ & Yes & No & $\begin{array}{l}\text { Rats, } \\
\text { Mice }\end{array}$ & {$[24,71]$} \\
\hline & Suramine & $\begin{array}{l}\text { Decrease tubular apoptosis via } \\
\text { caspase- } 3 \text {, and decreased } \\
\text { inflammation by reducing NF- } \kappa \beta \\
\text { activation and Il- } 1 \beta \text { and ICAM-1 } \\
\text { expression }\end{array}$ & Yes & No & Rats & {$[72]$} \\
\hline & Pentoxifylline & $\begin{array}{l}\text { Reduced tubular necrosis, cast } \\
\text { formation, leukocyte infiltration and } \\
\text { serum creatinine. }\end{array}$ & Yes & No & Rats & [76] \\
\hline & $\begin{array}{l}\text { Mesenchymal } \\
\text { stem-cells } \\
\text { injection }\end{array}$ & $\begin{array}{l}\text { Restored renal function and } \\
\text { increased reparative M2- } \\
\text { macrophage }\end{array}$ & Yes & No & Mice & {$[78,79]$} \\
\hline \multirow[t]{2}{*}{$\begin{array}{l}\text { Vaso- } \\
\text { constriction } \\
\text { inhibitor }\end{array}$} & $\begin{array}{l}\text { L-arginine } \\
\text { /moldosine }\end{array}$ & $\begin{array}{l}\text { Restored nitric oxide levels, renal } \\
\text { function, morphological alterations, } \\
\text { reduced TBARS and restored the } \\
\text { depleted renal antioxidant enzymes }\end{array}$ & Yes & No & Rats & [86] \\
\hline & rhEPO & $\begin{array}{l}\text { Suppressed the activities of NF- } \kappa B \\
\text { and iNOS and restored renal function }\end{array}$ & Yes & No & Rats & [89] \\
\hline
\end{tabular}

is controversial and human studies validating their use are scarce. The actual understanding of pathophysiological mechanisms involved in rhabdomyolysis is associated to experimental studies, and there is no current clinical application of such knowledge. New antioxidant and anti-inflammatory therapies have shown efficacy in animal models, neutralizing the deleterious effect of myoglobin. Therefore, controlled clinical trials are needed to evaluate the potential benefit of these approaches in the prevention or treatment of AKI secondary to rhabdomyolysis. Prospective studies may be required to better define long-term adverse effects of rhabdomyolysis, identify prognostic factors and define a management strategy. Until new specific treatments are available, classical supportive care strategies should be recommended.

\section{Disclosure Statement}

The authors of this manuscript state that they do not have any conflict of interests and nothing to disclose. 


\section{Kidney \\ Blood Pressure Research}

\section{Acknowledgements}

This work has been supported by grants from Instituto de Salud Carlos III (ISCIII)/ FEDER (Programa Miguel Servet: CP10/00479, PI13/00802 and PI14/00883) and the Spanish Society of Nephrology to Juan Antonio Moreno. Fundación Lilly, Fundación Renal Iñigo Alvarez de Toledo and ISCIII PI14/00386 to Jesus Egido. Fundación Conchita Rabago to Alfonso Rubio Navarro.

\section{References}

1 Bosch X, Poch E, Grau JM: Rhabdomyolysis and acute kidney injury. N Engl J Med 2009;361:62-72.

2 Bagley WH, Yang H, Shah KH: Rhabdomyolysis. Intern Emerg Med 2007;2:210-218.

3 Sauret JM, Marinides G, Wang GK: Rhabdomyolysis. Am Fam Physician 2002;65:907-912.

4 Holt SG, Moore KP: Pathogenesis and treatment of renal dysfunction in rhabdomyolysis. Intensive Care Med 2001;27:803-811.

5 Zimmerman JL, Shen MC: Rhabdomyolysis. Chest 2013;144:1058-1065.

6 de Meijer AR, Fikkers BG, de Keijzer MH, van Engelen BG, Drenth JP: Serum creatine kinase as predictor of clinical course in rhabdomyolysis: a 5-year intensive care survey. Intensive Care Med 2003;29:1121-1125.

7 Wen X, Peng Z, Kellum JA: Pathogenesis of acute kidney injury: effects of remote tissue damage on the kidney. Contrib Nephrol 2011;174:129-137.

8 Belliere J, Casemayou A, Ducasse L, Zakaroff-Girard A, Martins F, Iacovoni JS, Guilbeau-Frugier C, Buffin-Meyer B, Pipy B, Chauveau D, Schanstra JP, Bascands JL: Specific Macrophage Subtypes Influence the Progression of Rhabdomyolysis-Induced Kidney Injury. J Am Soc Nephrol 2014, DOI 10.1681/ ASN.2014040320

9 Khan FY: Rhabdomyolysis: a review of the literature. Neth J Med 2009;67:272-283.

10 Gburek J, Birn H, Verroust PJ, Goj B, Jacobsen C, Moestrup SK, Willnow TE, Christensen EI: Renal uptake of myoglobin is mediated by the endocytic receptors megalin and cubilin. Am J Physiol Renal Physiol 2003;285:F451-458.

11 Boutaud 0, Roberts LJ, 2nd: Mechanism-based therapeutic approaches to rhabdomyolysis-induced renal failure. Free Radic Biol Med 2011;51:1062-1067.

12 Kim SH, Chang JW, Kim SB, Park SK, Park JS, Lee SK: Myoglobin induces vascular cell adhesion molecule-1 expression through c-Src kinase-activator protein-1/nuclear factor-kappaB pathways. Nephron Exp Nephrol 2010;114:e48-60.

13 Petejova N, Martinek A: Acute kidney injury due to rhabdomyolysis and renal replacement therapy: a critical review. Crit Care 2014;18:224.

14 Wijayanti N, Katz N, Immenschuh S: Biology of heme in health and disease. Curr Med Chem 2004;11:981986.

15 Moore KP, Holt SG, Patel RP, Svistunenko DA, Zackert W, Goodier D, Reeder BJ, Clozel M, Anand R, Cooper CE, Morrow JD, Wilson MT, Darley-Usmar V, Roberts LJ, 2nd: A causative role for redox cycling of myoglobin and its inhibition by alkalinization in the pathogenesis and treatment of rhabdomyolysis-induced renal failure. J Biol Chem 1998;273:31731-31737.

16 Reeder BJ, Wilson MT: Hemoglobin and myoglobin associated oxidative stress: from molecular mechanisms to disease States. Curr Med Chem 2005;12:2741-2751.

17 Moreno JA, Martin-Cleary C, Gutierrez E, Toldos O, Blanco-Colio LM, Praga M, Ortiz A, Egido J: AKI associated with macroscopic glomerular hematuria: clinical and pathophysiologic consequences. Clin J Am Soc Nephrol 2012;7:175-184.

18 Vuletich JL, Osawa Y, Aviram M: Enhanced lipid oxidation by oxidatively modified myoglobin: role of protein-bound heme. Biochem Biophys Res Commun 2000;269:647-651.

19 Jang HR, Rabb H: The innate immune response in ischemic acute kidney injury. Clin Immunol 2009;130:4150 .

20 Gonzalez-Michaca L, Farrugia G, Croatt AJ, Alam J, Nath KA: Heme: a determinant of life and death in renal tubular epithelial cells. Am J Physiol Renal Physiol 2004;286:F370-377. 


\section{Kidney \\ Blood Pressure Research}

Kidney Blood Press Res 2015;40:520-532

\begin{tabular}{l|l}
\hline DOI: 10.1159/000368528 & (C) 2015 The Author(s). Published by S. Karger AG, Base
\end{tabular}

Published online: October 20, 2015

www.karger.com/kbr

21 Moreno JA, Martin-Cleary C, Gutierrez E, Rubio-Navarro A, Ortiz A, Praga M, Egido J: Haematuria: the forgotten CKD factor? Nephrol Dial Transplant 2012;27:28-34.

22 Wagener FA, Feldman E, de Witte T, Abraham NG: Heme induces the expression of adhesion molecules ICAM-1, VCAM-1, and E selectin in vascular endothelial cells. Proc Soc Exp Biol Med 1997;216:456-463.

23 Graca-Souza AV, Arruda MA, de Freitas MS, Barja-Fidalgo C, Oliveira PL: Neutrophil activation by heme: implications for inflammatory processes. Blood 2002;99:4160-4165.

24 Kim JH, Lee DW, Jung MH, Cho HS, Jeon DH, Chang SH, Park DJ: Macrophage depletion ameliorates glycerolinduced acute kidney injury in mice. Nephron Exp Nephrol 2014;128:21-29.

25 Komada T, Usui F, Kawashima A, Kimura H, Karasawa T, Inoue Y, Kobayashi M, Mizushina Y, Kasahara T, Taniguchi S, Muto S, Nagata D, Takahashi M: Role of NLRP3 Inflammasomes for Rhabdomyolysis-induced Acute Kidney Injury. Sci Rep 2015;5:10901.

26 Zager RA, Johnson AC, Hanson SY: Proximal tubular cytochrome c efflux: determinant, and potential marker, of mitochondrial injury. Kidney Int 2004;65:2123-2134.

27 Plotnikov EY, Chupyrkina AA, Pevzner IB, Isaev NK, Zorov DB: Myoglobin causes oxidative stress, increase of NO production and dysfunction of kidney's mitochondria. Biochim Biophys Acta 2009;1792:796-803.

28 Homsi E, Janino P, de Faria JB: Role of caspases on cell death, inflammation, and cell cycle in glycerolinduced acute renal failure. Kidney Int 2006;69:1385-1392.

29 Davis RJ: Signal transduction by the JNK group of MAP kinases. Cell 2000;103:239-252.

30 Ishizuka S, Yano T, Hagiwara K, Sone M, Nihei H, Ozasa H, Horikawa S: Extracellular signal-regulated kinase mediates renal regeneration in rats with myoglobinuric acute renal injury. Biochem Biophys Res Commun 1999;254:88-92.

31 Bonventre JV, Weinberg JM: Recent advances in the pathophysiology of ischemic acute renal failure. J Am Soc Nephrol 2003;14:2199-2210.

32 Thomsen JH, Etzerodt A, Svendsen P, Moestrup SK: The haptoglobin-CD163-heme oxygenase-1 pathway for hemoglobin scavenging. Oxid Med Cell Longev 2013;2013:523652.

33 Nath KA, Haggard JJ, Croatt AJ, Grande JP, Poss KD, Alam J: The indispensability of heme oxygenase-1 in protecting against acute heme protein-induced toxicity in vivo. Am J Pathol 2000;156:1527-1535.

34 Otterbein LE, Bach FH, Alam J, Soares M, Tao Lu H, Wysk M, Davis RJ, Flavell RA, Choi AM: Carbon monoxide has anti-inflammatory effects involving the mitogen-activated protein kinase pathway. Nat Med 2000;6:422-428.

35 Berberat PO, Katori M, Kaczmarek E, Anselmo D, Lassman C, Ke B, Shen X, Busuttil RW, Yamashita K, Csizmadia E, Tyagi S, Otterbein LE, Brouard S, Tobiasch E, Bach FH, Kupiec-Weglinski JW, Soares MP: Heavy chain ferritin acts as an antiapoptotic gene that protects livers from ischemia reperfusion injury. FASEB J 2003;17:1724-1726.

36 Wegiel B, Otterbein LE: Go green: the anti-inflammatory effects of biliverdin reductase. Front Pharmacol 2012;3:47.

37 Gabow PA, Kaehny WD, Kelleher SP: The spectrum of rhabdomyolysis. Medicine (Baltimore) 1982;61:141152.

38 Lippi G, Sanchis-Gomar F, Salvagno GL, Aloe R, Schena F, Guidi GC: Variation of serum and urinary neutrophil gelatinase associated lipocalin (ngal) after strenuous physical exercise. Clin Chem Lab Med 2012;50:1585-1589.

39 Antonucci E, Lippi G, Ticinesi A, Pigna F, Guida L, Morelli I, Nouvenne A, Borghi L, Meschi T: Neutrophil gelatinase-associated lipocalin (ngal): A promising biomarker for the early diagnosis of acute kidney injury (aki). Acta Biomed 2014;85:289-294.

40 Wang B, Chen G, Zhang J, Xue J, Cao Y, Wu Y: Increased neutrophil gelatinase-associated lipocalin is associated with mortality and multiple organ dysfunction syndrome in severe sepsis and septic shock. Shock 2015;44:234-238.

41 Koyner JL, Vaidya VS, Bennett MR, Ma Q Worcester E, Akhter SA, Raman J, Jeevanandam V, O'Connor MF, Devarajan P, Bonventre JV, Murray PT: Urinary biomarkers in the clinical prognosis and early detection of acute kidney injury. Clin J Am Soc Nephrol 2010;5:2154-2165.

42 Sever MS, Vanholder R, Lameire N: Management of crush-related injuries after disasters. N Engl J Med 2006;354:1052-1063.

43 Heyman SN, Greenbaum R, Shina A, Rosen S, Brezis M: Myoglobinuric acute renal failure in the rat: a role for acidosis? Exp Nephrol 1997;5:210-216. 


\section{Kidney \\ Blood Pressure Research}

Kidney Blood Press Res 2015;40:520-532

\begin{tabular}{l|l}
\hline DOI: 10.1159/000368528 & (C) 2015 The Author(s). Published by S. Karger AG, Base
\end{tabular}

Published online: October 20, 2015

www.karger.com/kb

Rhabdomyolysis

44 Brown CV, Rhee P, Chan L, Evans K, Demetriades D, Velmahos GC: Preventing renal failure in patients with rhabdomyolysis: do bicarbonate and mannitol make a difference? J Trauma 2004;56:1191-1196.

45 Homsi E, Barreiro MF, Orlando JM, Higa EM: Prophylaxis of acute renal failure in patients with rhabdomyolysis. Ren Fail 1997;19:283-288.

46 Vanholder R, Sever MS, Erek E, Lameire N: Rhabdomyolysis. J Am Soc Nephrol 2000;11:1553-1561.

47 Ozguc H, Kahveci N, Akkose S, Serdar Z, Balci V, Ocak O: Effects of different resuscitation fluids on tissue blood flow and oxidant injury in experimental rhabdomyolysis. Crit Care Med 2005;33:2579-2586.

48 Lameire N, Van Biesen W, Vanholder R: Acute renal failure. Lancet 2005;365:417-430.

49 Sorrentino SA, Kielstein JT, Lukasz A, Sorrentino JN, Gohrbandt B, Haller H, Schmidt BM: High permeability dialysis membrane allows effective removal of myoglobin in acute kidney injury resulting from rhabdomyolysis. Crit Care Med 2011;39:184-186.

50 Naka T, Jones D, Baldwin I, Fealy N, Bates S, Goehl H, Morgera S, Neumayer HH, Bellomo R: Myoglobin clearance by super high-flux hemofiltration in a case of severe rhabdomyolysis: a case report. Crit Care 2005;9:R90-95.

51 Premru V, Kovac J, Buturovic-Ponikvar J, Ponikvar R: High cut-off membrane hemodiafiltration in myoglobinuric acute renal failure: a case series. Ther Apher Dial 2011;15:287-291.

52 Zhang L, Kang Y, Fu P, Cao Y, Shi Y, Liu F, Hu Z, Su B, Tang W, Qin W: Myoglobin clearance by continuous venous-venous haemofiltration in rhabdomyolysis with acute kidney injury: a case series. Injury 2012;43:619-623.

53 Tang W, Chen Z, Wu W, Qiu H, Bo H, Zhang L, Fu P: Renal protective effects of early continuous venovenous hemofiltration in rhabdomyolysis: improved renal mitochondrial dysfunction and inhibited apoptosis. Artif Organs 2013;37:390-400.

54 Swaroop R, Zabaneh R, Parimoo N: Plasmapheresis in a patient with rhabdomyolysis: a case report. Cases J 2009;2:8138.

55 Ronco C: Extracorporeal therapies in acute rhabdomyolysis and myoglobin clearance. Crit Care 2005;9:141-142.

56 Paller MS: Hemoglobin- and myoglobin-induced acute renal failure in rats: role of iron in nephrotoxicity. Am J Physiol 1988;255:F539-544.

57 Reeder BJ, Wilson MT: Desferrioxamine inhibits production of cytotoxic heme to protein cross-linked myoglobin: a mechanism to protect against oxidative stress without iron chelation. Chem Res Toxicol 2005;18:1004-1011.

58 Groebler LK, Liu J, Shanu A, Codd R, Witting PK: Comparing the potential renal protective activity of desferrioxamine B and the novel chelator desferrioxamine B-N-(3-hydroxyadamant-1-yl)carboxamide in a cell model of myoglobinuria. Biochem J 2011;435:669-677.

59 Kontoghiorghes GJ, Pattichi K, Hadjigavriel M, Kolnagou A: Transfusional iron overload and chelation therapy with deferoxamine and deferiprone (L1). Transfus Sci 2000;23:211-223.

60 Anderson BJ: Paracetamol (Acetaminophen): mechanisms of action. Paediatr Anaesth 2008;18:915-921.

61 Boutaud O, Moore KP, Reeder BJ, Harry D, Howie AJ, Wang S, Carney CK, Masterson TS, Amin T, Wright DW, Wilson MT, Oates JA, Roberts LJ, 2nd: Acetaminophen inhibits hemoprotein-catalyzed lipid peroxidation and attenuates rhabdomyolysis-induced renal failure. Proc Natl Acad Sci U S A 2010;107:2699-2704.

62 Luo J, Tsuji T, Yasuda H, Sun Y, Fujigaki Y, Hishida A: The molecular mechanisms of the attenuation of cisplatin-induced acute renal failure by N-acetylcysteine in rats. Nephrol Dial Transplant 2008;23:21982205.

63 Nitescu N, Ricksten SE, Marcussen N, Haraldsson B, Nilsson U, Basu S, Guron G: N-acetylcysteine attenuates kidney injury in rats subjected to renal ischaemia-reperfusion. Nephrol Dial Transplant 2006;21:12401247.

64 Shimizu MH, Coimbra TM, de Araujo M, Menezes LF, Seguro AC: N-acetylcysteine attenuates the progression of chronic renal failure. Kidney Int 2005;68:2208-2217.

65 Kim JH, Lee SS, Jung MH, Yeo HD, Kim HJ, Yang JI, Roh GS, Chang SH, Park DJ: N-acetylcysteine attenuates glycerol-induced acute kidney injury by regulating MAPKs and Bcl-2 family proteins. Nephrol Dial Transplant 2010;25:1435-1443.

66 Machlin LJ, Bendich A: Free radical tissue damage: protective role of antioxidant nutrients. FASEB J 1987;1:441-445. 


\section{Kidney \\ Blood Pressure Research}

Kidney Blood Press Res 2015;40:520-532

\begin{tabular}{l|l}
\hline DOI: 10.1159/000368528 & (C) 2015 The Author(s). Published by S. Karger AG, Base
\end{tabular}

Published online: October 20, 2015

www.karger.com/kbr

67 Huerta-Alardin AL, Varon J, Marik PE: Bench-to-bedside review: Rhabdomyolysis -- an overview for clinicians. Crit Care 2005;9:158-169.

68 Groebler LK, Wang XS, Kim HB, Shanu A, Hossain F, McMahon AC, Witting PK: Cosupplementation with a synthetic, lipid-soluble polyphenol and vitamin $\mathrm{C}$ inhibits oxidative damage and improves vascular function yet does not inhibit acute renal injury in an animal model of rhabdomyolysis. Free Radic Biol Med 2012;52:1918-1928.

69 Rodrigo R, Bosco C, Herrera P, Rivera G: Amelioration of myoglobinuric renal damage in rats by chronic exposure to flavonol-rich red wine. Nephrol Dial Transplant 2004;19:2237-2244.

70 Aydogdu N, Atmaca G, Yalcin O, Taskiran R, Tastekin E, Kaymak K: Protective effects of L-carnitine on myoglobinuric acute renal failure in rats. Clin Exp Pharmacol Physiol 2006;33:119-124.

71 Van Rooijen N, Sanders A: Liposome mediated depletion of macrophages: mechanism of action, preparation of liposomes and applications. J Immunol Methods 1994;174:83-93.

72 Ko GJ, Boo CS, Jo SK, Cho WY, Kim HK: Macrophages contribute to the development of renal fibrosis following ischaemia/reperfusion-induced acute kidney injury. Nephrol Dial Transplant 2008;23:842-852.

73 Liu N, Tolbert E, Pang M, Ponnusamy M, Yan H, Zhuang S: Suramin inhibits renal fibrosis in chronic kidney disease. J Am Soc Nephrol 2011;22:1064-1075.

74 Korrapati MC, Shaner BE, Schnellmann RG: Recovery from glycerol-induced acute kidney injury is accelerated by suramin. J Pharmacol Exp Ther 2012;341:126-136.

75 Tsai TJ, Lin RH, Chang CC, Chen YM, Chen CF, Ko FN, Teng CM: Vasodilator agents modulate rat glomerular mesangial cell growth and collagen synthesis. Nephron 1995;70:91-99.

76 Strutz F, Heeg M, Kochsiek T, Siemers G, Zeisberg M, Muller GA: Effects of pentoxifylline, pentifylline and gamma-interferon on proliferation, differentiation, and matrix synthesis of human renal fibroblasts. Nephrol Dial Transplant 2000;15:1535-1546.

77 Savic V, Vlahovic P, Djordjevic V, Mitic-Zlatkovic M, Avramovic V, Stefanovic V: Nephroprotective effects of pentoxifylline in experimental myoglobinuric acute renal failure. Pathol Biol (Paris) 2002;50:599-607.

78 de Almeida DC, Donizetti-Oliveira C, Barbosa-Costa P, Origassa CS, Camara NO: In search of mechanisms associated with mesenchymal stem cell-based therapies for acute kidney injury. Clin Biochem Rev 2013;34:131-144.

79 Duffy MM, Griffin MD: Back from the brink: a mesenchymal stem cell infusion rescues kidney function in acute experimental rhabdomyolysis. Stem Cell Res Ther 2014;5:109.

80 Lalu MM, McIntyre L, Pugliese C, Fergusson D, Winston BW, Marshall JC, Granton J, Stewart DJ, Canadian Critical Care Trials G: Safety of cell therapy with mesenchymal stromal cells (SafeCell): a systematic review and meta-analysis of clinical trials. PLoS One 2012;7:e47559.

81 Jeong H, Yim HW, Cho YS, Kim YI, Jeong SN, Kim HB, Oh IH: Efficacy and safety of stem cell therapies for patients with stroke: a systematic review and single arm meta-analysis. Int J Stem Cells 2014;7:63-69.

82 Taniguchi T: Cytokine adsorbing columns. Contrib Nephrol 2010;166:134-141.

83 Peng ZY, Carter MJ, Kellum JA: Effects of hemoadsorption on cytokine removal and short-term survival in septic rats. Crit Care Med 2008;36:1573-1577.

84 Basu R, Pathak S, Goyal J, Chaudhry R, Goel RB, Barwal A: Use of a novel hemoadsorption device for cytokine removal as adjuvant therapy in a patient with septic shock with multi-organ dysfunction: A case study. Indian J Crit Care Med 2014;18:822-824.

85 Pattnaik SK, Panda B: CytoSorb-friend or foe!! Indian J Crit Care Med 2015;19:296.

86 Chander V, Chopra K: Molsidomine, a nitric oxide donor and L-arginine protects against rhabdomyolysisinduced myoglobinuric acute renal failure. Biochim Biophys Acta 2005;1723:208-214.

87 Newaz MA, Oyekan AO: Vascular responses to endothelin-1, angiotensin-II, and U46619 in glycerol-induced acute renal failure. J Cardiovasc Pharmacol 2001;38:569-577.

88 Sharples EJ, Patel N, Brown P, Stewart K, Mota-Philipe H, Sheaff M, Kieswich J, Allen D, Harwood S, Raftery M, Thiemermann C, Yaqoob MM: Erythropoietin protects the kidney against the injury and dysfunction caused by ischemia-reperfusion. J Am Soc Nephrol 2004;15:2115-2124.

89 Yang FL, Subeq YM, Chiu YH, Lee RP, Lee CJ, Hsu BG: Recombinant human erythropoietin reduces rhabdomyolysis-induced acute renal failure in rats. Injury 2012;43:367-373.

90 Bokemeyer C, Aapro MS, Courdi A, Foubert J, Link H, Osterborg A, Repetto L, Soubeyran P, European Organisation for R, Treatment of Cancer Taskforce for the E: EORTC guidelines for the use of erythropoietic proteins in anaemic patients with cancer: 2006 update. Eur J Cancer 2007;43:258-270. 